\title{
Law Enforcement on Fiducian Security Objects Due to Withdrawal of Fiducia Security Objects
}

\section{Angga Kusumah ${ }^{*}$ and Aryani Witasari**)}

*) Student of Master of Law, Faculty of Law, Universitas Islam Sultan Agung Semarang, Indonesia, E-mail: badgeurangga@gmail.com

*) Faculty of Law, Universitas Islam Sultan Agung Semarang,

\begin{abstract}
.
The objectives of this study are: Knowing and analyzing Law Enforcement against Fiduciary Guarantee Objects Post-Constitutional Court Decision Number 18 / PUU-XVII / 2019. Knowing and analyzing the obstacles that occur in law enforcement on the object of fiduciary security. In this research, the approach method used is the sociological juridical approach. The research specification used in this research is descriptive analysis. Based on the research, it is concluded that law enforcement on the object of fiduciary guarantee after the Constitutional Court Decision Number 18 / PUU-XVII / 2019 is preventive that has been carried out including: reading of rights and obligations and signing signatures by each party, registration of Fiduciary Security at the Ministry of Law and Human Rights, insuring units and parties, and give warning 3 (three) times before securing Fiduciary Security goods. The repressions that have been carried out include administrative law enforcement, criminal law enforcement and civil law enforcement. Constraints that Occur in Law Enforcement of the Object of the Fiduciary Guarantee and the solution is insufficient evidence, the solution is to look for such evidence; If the collateral object has not been found, the investigator needs to carry out further investigation; The suspect is not present, runs away, does not have a permanent place of residence or his identity is not clear, the solution is to carry out further investigations. Responding to the facts above, it is necessary that the Fiduciary Security Law be more socialized to the public,

Keywords: Law Enforcement; Fiduciary Guarantee; Constitutional Court.
\end{abstract}

\section{Introduction}

Economic development, as part of national development is one of the efforts to achieve a just and prosperous society based on Pancasila and the 1945 Constitution. In order to maintain and continue sustainable development, development actors, both government and society, both individuals and legal entities need bid funds. Along with increasing development, needs also increase towards funding, most of the funds needed to meet these needs are obtained through borrowing and lending 1 .

Economic development in Indonesia requires substantial funds, so it is necessary to expand the means of providing funds needed by the community ${ }^{2}$ therefore, "The government forms an institution to help business people who need

\footnotetext{
${ }^{1}$ Kashadi and Purwahid Patrik. (2009). Hukum Jaminan. Semarang: BP Undip. p. 171.

2 Jenie, Siti Ismijati.(1996). Beberapa Perjanjian Yang Berkenaan Dengan Kegiatan Pembiayaan, Bahan Penataran Dosen Hukum Perdata. Yoyakarta : Fakultas Hukum UGM, p. 1.
} 
capital called a Financing Institution" 3. Financing Institution is a "business entity that carries out financing activities in the form of provision of funds or capital goods" 4 . The development of financing institutions or what is often known as Consumer Financing Institutions are increasing due to the fact that existing banks are deemed insufficient to cope with various financial needs for the community. Another cause is "limited coverage of credit spread by banks and limited funds" 5 .

The juridical guarantee function is for legal certainty of repayment of debts in a credit / payable agreement or certainty of realization of an achievement in an agreement. This legal certainty is by increasing guarantees through guarantee institutions which are known in Indonesian law. Material guarantee institutions can be in the form of mortgage rights, mortgages, Credit Verband, fiduciary and pawn ${ }^{6}$.

The fiduciary security of the movable object which is the object of the guarantee must be registered with the fiduciary security office to obtain a fiduciary guarantee certificate. This registration is electronic. However, sometimes the debtor who provides the fiduciary guarantee does not carry out what has been agreed with the creditor. The form of default or broken promise can be in the form of not paying debts to creditors, paying but being late and so on. Of course, with this default, it causes losses to creditors, thus making creditors want to execute objects that have been fiduciary. However, the execution by creditors through debt collector services sometimes creates new problems between creditors and debtors.

The objectives of this research are: Knowing and analyzing Law Enforcement against the Objects of Post-Judgment Fiduciary Guarantee Constitutional Court Number 18 / PUU-XVII / 2019 and Knowing and analyzing the obstacles that occur in law enforcement on the object of fiduciary security

\section{Research methods}

In this research, the approach method used is the sociological juridical approach. The sociological juridical approach (socio-legal approach) is intended to study and examine reciprocal relationships that are associated in real terms with other social variables. The research specifications used in this research are descriptive analysis.

\section{Result and Discussion}

\subsection{Law Enforcement against the Objects of Post-Judgment Fiduciary Guarantee Constitutional Court Number 18 / PUU-XVII / 2019.}

\footnotetext{
3 Pusat Kebijakan Perdagangan Dalam Negeri. (2013). Analisis Peran Lembaga Pembiayaan Dalam Pengembangan UMKM. Badan Pengkajian dan Pengembangan Kebijakan Perdagangan Kementerian Perdagangan. Jakarta, p. 1.

${ }^{4}$ See Article 1 Number 1 Presidential Decree No. 9 of 2009 concerning Financing Institutions.

5 Fuady, Munir .(2012). Hukum Tentang Pembiayaan dalam Teori dan Praktek. Bandung: Citra Aditya Bakti. p. 2.

${ }^{6}$ Badrulzaman, Mariam Darus. (1998). Kerangka Hukum Jaminan Indonesia Dalam Hukum Jaminan Indonesia Seri Dasar Hukum Ekonomi. Bandung : Citra Aditya Bakti. p. 68.
} 
In a fiduciary agreement, the object as a fiduciary object is still under the control of the owner of the object (debtor) and is not controlled by the creditor, so in this case it is the handover of the object without giving up ownership of physical object. Creditors entrust the debtor to continue to use the collateral object according to its function. ${ }^{7}$

Prior to the enactment of Act No. 42 of 1999 concerning Fiduciary Guarantee, the existence of fiduciary practices in Indonesia was based on the jurisprudence of the Dutch Hoge Raad known as the Bier Broumerij Arrest ruling, where the judge for the first time legalized the existence of such a guarantee mechanism. Before the Fiduciary Guarantee Act, there were very few guidelines that could be held as references for the application of the fiduciary instrument. There are also several statutory provisions that pertain to fiduciary as an instrument of guarantee. Even so, in general there is no technical guide regarding the implementation of the fiduciary instrument. The birth of the fiduciary guarantee is purely based on the provisions of Article 1320 jo 1338 of the Civil Code (hereinafter referred to as the Civil Code) regarding freedom of contract. ${ }^{8}$

In connection with the legal liability to the fiduciary who transfers or leases the object of fiduciary security to another party without the written consent of the fiduciary recipient, then based on the formulation of the criminal act mentioned above, criminal liability may be subject to criminal law, because the actions committed by the fiduciary have met the elements. - an element of the crime.

So the giver of fuduciary in this case violates article 23 paragraph (2) Act No. 42 of 1999 concerning Fiduciary Security, which states that "the fiduciary is prohibited from transferring, pawning or renting to other parties, objects that are objects of fiduciary security which are not inventory objects, except with the prior written approval of the fiduciary recipient.

Law enforcement on the object of fiduciary guarantee after the decision The Constitutional Court Number 18 / PUU-XVII / 2019 is preventive action that has been carried out including: reading of rights and obligations and signing a signature by each party, registering Fiduciary Security at the Ministry of Law and Human Rights, insuring the unit and parties, and giving 3 (three) warnings times before securing Fiduciary Guarantee goods. The repressions that have been carried out include administrative law enforcement, criminal law enforcement and civil law enforcement.

\subsection{Constraints that Occur in Law Enforcement of the Object of the Fiduciary Guarantee and their solutions}

To prevent losses for finance companies, order and smoothness of payments need to be guaranteed, and considering that the credit agreement requires a certain amount of money and many consumers are negligent in making payments, it is necessary to have a guarantee. According to Sri Soedwi M. Sofwan, the guarantee law stated: "By using the purchased object as collateral, it is hoped

\footnotetext{
7 Umar Ma'ruf and Agus Budianto. Law Enforcement Against Transfer of Objects Fiduciary in Kudus Police, Jurnal Daulat Hukum Volume 2 Issue 1, March 2019 ISSN: 2614-560X.

${ }^{8}$ Kamello, Tan. (2014). Hukum Jaminan Fidusia, suatu kebutuhan yang didambakan. Bandung : Alumni. p. 45.
} 
that the juridical construction will regulate the credit facility of an item. In this regulation, there is legal certainty for credit-giving institutions. So that credit institutions must be balanced with large numbers because of the guarantee institution, with a long period of time provided and relatively low interest rates." 9

There have been various laws relating to guarantee law, which are used as a juridical concept to regulate future guarantees. As a debt imposition to regulate legal protection for creditors and debtors, to regulate a legal relationship between the parties, a guarantee law is required.

According to Act No. 4 of 1996 concerning Mortgage Rights, for the rights and so on (hereinafter referred to as the Mortgage Rights Law), the definition of fiduciary security is expanded to mean movable objects that are tangible or intangible and immovable objects that cannot be burdened with mortgage right ${ }^{10}$. Fiduciary security is a right to guarantee a movable object that remains under the control of the fiduciary, as collateral for the repayment of certain debts which gives the fiduciary priority over other creditors.

Many business people use financing institutions when they need funds or capital goods for the benefit of the company. In line with that, since 1988 the government has taken various policies to further strengthen the national financial institution system through the development and expansion of various types of financial institutions, including financial institutions, with the aim of "expanding the provision of alternative financing for the business / business world in line with the increasing need for funds to support business activities." 11

Constraints that Occur in Law Enforcement of the Object of the Fiduciary Guarantee and the solution, namely Insufficient evidence, the solution is to look for these tools; If the collateral object has not been found, the investigator needs to carry out further investigation; The suspect is not present, runs away, does not have a permanent place of residence or his identity is not clear, the solution is to carry out further investigations. Responding to the facts above, it is necessary that the Fiduciary Security Law be more socialized to the public, so that each party in it understands the rights and obligations as well as the limitations in carrying out a fiduciary agreement to minimize the occurrence of embezzlement of fiduciary goods.

\section{Closing}

Law enforcement on the object of fiduciary guarantee after the decision The Constitutional Court Number 18 / PUU-XVII / 2019 is preventive action that has been carried out including: reading of rights and obligations and signing a signature by each party, registering Fiduciary Security at the Ministry of Law and

\footnotetext{
9 Sofwan, Sri Soedewi Masjchoen. (1997). Beberapa Masalah Pelaksanaan Lembaga Khususnya Fidusia di dalam Praktik dan Pelaksanaannya di Indonesia. Jakarta: Fakultas Hukum Universitas Gajah Mada. p.5.

10 Widyadharma, Ignatius Ridwan. (1999). Hukum Jaminan Fidusia Pedoman Praktis, Cetakan ke-1. Semarang: Universitas Diponegoro. p. 7.

11 Siamat, Dahlan. (2001). Manajemen Lembaga Keuangan. Jakarta: Fakultas Ekonomi Universitas Indonesia. p. 281.
} 
Human Rights, insuring the unit and parties, and giving 3 (three) warnings times before securing Fiduciary Guarantee goods. The repressions that have been carried out include administrative law enforcement, criminal law enforcement and civil law enforcement.

Constraints that Occur in Law Enforcement of the Object of the Fiduciary Guarantee and the solution, namely Insufficient evidence, the solution is to look for these tools; If the collateral object has not been found, the investigator needs to carry out further investigation; The suspect is not present, runs away, does not have a permanent place of residence or his identity is not clear, the solution is to carry out further investigations. Responding to the facts above, it is necessary that the Fiduciary Security Law be more socialized to the public, so that each party in it understands the rights and obligations as well as the limitations in carrying out a fiduciary agreement to minimize the occurrence of embezzlement of fiduciary goods.

The government in the future must make arrangements immediately to provide certainty to the business world by bringing a new concept following the issuance of the Constitutional Court decision Number 18 / PUU-XVII / 2019. Then with the issuance of this decision, the business world will find obstacles considering that the process of executing and selling objects which are Fiduciary Collateral is not as easy as before the issuance of the Constitutional Court decision Number 18 / PUU-XVII / 2019.

\section{References}

\section{Journal:}

[1] Umar Ma'ruf and Agus Budianto. Law Enforcement against Transfer of Objects Fiduciary in Kudus Police, Jurnal Daulat Hukum Volume 2 Issue 1, March 2019 ISSN: 2614-560X.

\section{Books:}

[1] Badrulzaman, Mariam Darus. (1998). Kerangka Hukum Jaminan Indonesia Dalam Hukum Jaminan Indonesia Seri Dasar Hukum Ekonomi. Bandung : Citra Aditya Bakti.

[2] Fuady, Munir. (2012). Hukum Tentang Pembiayaan dalam Teori dan Praktek. Bandung: Citra Aditya Bakti.

[3] Jenie, Siti Ismijati. (1996). Beberapa Perjanjian Yang Berkenaan Dengan Kegiatan Pembiayaan, Bahan Penataran Dosen Hukum Perdata. Yoyakarta : Fakultas Hukum UGM.

[4] Kamello, Tan. (2014). Hukum Jaminan Fiducia, suatu kebutuhan yang didambakan. Bandung : Alumni.

[5] Kashadi and Purwahid Patrik. (2009). Hukum Jaminan. Semarang : BP Undip.

[6] Pusat Kebijakan Perdagangan Dalam Negeri. (2013). Analisis Peran Lembaga Pembiayaan Dalam Pengembangan UMKM. Badan Pengkajian dan Pengembangan Kebijakan Perdagangan Kementerian Perdagangan. Jakarta

[7] Siamat, Dahlan. (2001). Manajemen Lembaga Keuangan. Jakarta: Fakultas Ekonomi Universitas Indonesia. 
[8] Sofwan, Sri Soedewi Masjchoen. (1997). Beberapa Masalah Pelaksanaan Lembaga Khususnya Fiducia di dalam Praktik dan Pelaksanaannya di Indonesia. Jakarta: Fakultas Hukum Universitas Gajah Mada. .

[9] Widyadharma, Ignatius Ridwan. (1999). Hukum Jaminan Fiducia Pedoman Praktis, Cetakan ke-1. Semarang: Universitas Diponegoro. 